\title{
Redesigning Educational Delivery Systems: The Needs and Options for Continuous Learning during the Coronavirus (COVID-19) Pandemic in Nigeria
}

\author{
Emeka Joshua Chukwuemeka \\ Department of Educational Technology Federal University of Technology, Minna, Niger State, Nigeria \\ ORCID: 0000-0002-1985-8002 \\ Samaila Dominic \\ Department of Educational Technology Federal University of Technology, Minna, Niger State, Nigeria \\ ORCID: 0000-0002-5684-9332 \\ Mary Ayanjoke Kareem \\ Department of Educational Technology Federal University of Technology, Minna, Niger State, Nigeria \\ ORCID: 0000-0003-2536-177X \\ Ibrahim Ango Mailafia \\ Department of Science Education, Kebbi State University of Science and Technology, Aliero, Nigeria \\ ORCID: 0000-0001-8036-3757
}

Received: 20 Apr 2020

Accepted: 28 Jun 2020

\begin{abstract}
Education has been one of the worst-hit sectors of the economy since the detection of the first index case of Covid-19 in Nigeria on February 27, 2020. Like many affected countries of the world, the Federal government of Nigeria has taken several necessary precautionary measures to curtail the spread of the disease. This has led to the suspension of all educational activities especially in-class teaching and learning processes. This paper studied the state of education in Nigeria and the effort of government towards continuous education in comparison to the measures put in place by other developing countries during the COVID-19 pandemic. The paper equally reviewed five different available and popular online learning platforms that can be implemented by the government to provide start-up educational programs that would help to keep students on course by learning remotely from home throughout the period of Covid19 pandemic. These include Distance Learning, Social media, Virtual Classroom, M-Learning, and Flipped classroom. Implementation of these online forms of education will successfully offer alternatives and ensure continuous education presently and in the future. The recommendations of this study would be useful even for other developing countries that are yet to discover any alternative to the disrupted inclass learning activities so that their students will start to learn from home.
\end{abstract}

Keywords: COVID-19, Coronavirus, open and distance learning, social media, virtual classroom, mobile learning, flipped classroom

\section{INTRODUCTION}

Since the outbreak of an acute respiratory disease caused by Coronavirus Sars-Cov-2 from Wuhan, Hubei province in China in December 2019, the World Health Organisation (WHO) as a matter of international concern declared the disease a global public health emergency that poses threat to the social coexistence, 


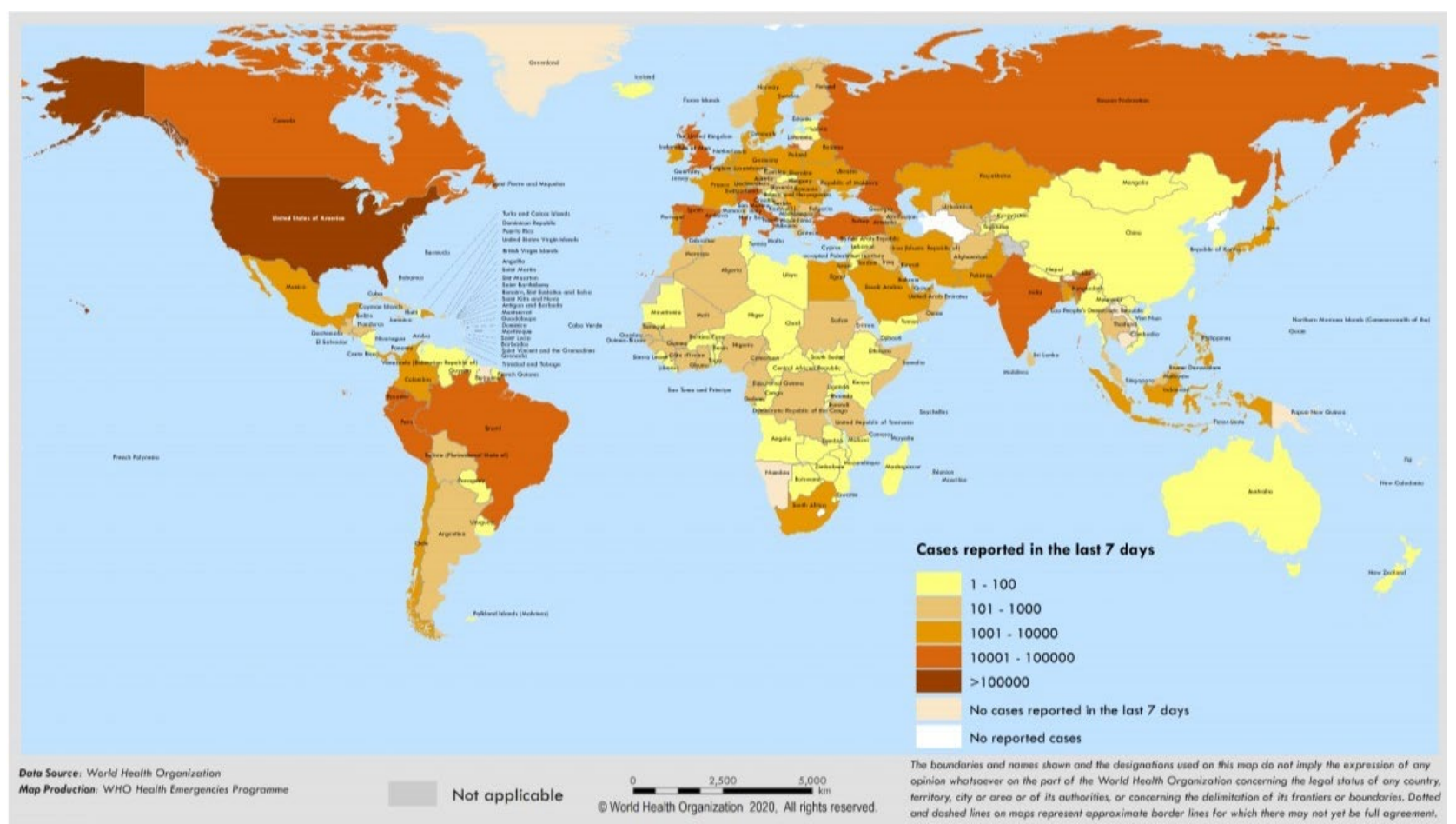

Figure 1. Number of Confirmed Covid-19 Cases Reported in the last Seven Days by Country, Territory or Area, between $25^{\text {th }}$ April to $1^{\text {st }}$ May, 2020

Source: WHO (2020).

global economy and sustainability. This is because of its obvious impact on all aspects of human activities which has caused a difficult time for the global community throughout the first quarter of year 2020 (Akwa \& Maingi, 2020; Demuyakor, 2020).

Thus, many countries across the globe have responded seriously in a cooperative effort to fight the pandemic (WHO, 2020a, 2020b; World Bank, 2020). Coronavirus is a serious health problem that requires cooperation and precautionary measures to be taken to stop the spread of the virus. According to Fong et al. (2020), countries worldwide have taken measures such as declaring a state of emergency, improving medical provision, minimizing mass gathering, closing borders, recreational centres, schools, libraries, businesses, religious and sporting activities, also enforcing strict city surveillance, individual quarantines and building large-scale isolations centres. On the other hand, COVID-19 awareness and sensitisation programs were also mediums adopted by some governments. The study of Akwa and Maingi (2020) on the awareness and perceptions of Cameroonian population on the existence and spread of COVID-19, revealed that the greater proportion of Cameroon population were aware of the COVID 19 existence, transmission and preventive strategies, which has helped in the reduction of the spread of the disease.

Even with these efforts made, many more people continued to get infected with the disease. As at April 30 2020, coronavirus has infected 3,175,207 persons worldwide, with over 2 million active cases and 224,172 deaths recorded (Johns Hopkins University of medicine, Online Map: J. H. Uni. 2020). The Nigeria Centre for Disease Control (NCDC Online Daily Update, 2020) revealed that among the global index published by the Johns Hopkins University of medicine, 1,932 cases are in Nigeria. Out of which 1,555 were active cases, 319 were successfully treated and 58 deaths were recorded.

The advent of coronavirus in Nigeria has left both the Federal and State government under a state of high uncertainty, struggling with the economy, political and educational challenges. Since the detection of the first case of COVID-19 on $27^{\text {th }}$ February, 2020 in Nigeria, the Federal government has taken precautionary measures to encourage social distancing thereby limiting the spread of the virus. These measures are similar to the ones the country had taken during the outbreak of the Ebola virus disease in 2014, even though the outbreak was limited both in terms of number of infected cases, geographical scope and deaths (Otu et al., 
2017). The Federal government of Nigeria through the minister of education has on $23^{\text {rd }}$ March, 2020 announced the immediate suspension of all educational activities. Schools (including elementary, secondary and tertiary institutions) in the country have suspended all classroom activities and other academic events such as conferences and seminars among others, as a way of promoting the stay at home principle which is the only ray of hope for safety pending when a vaccine or cure to the disease will be discovered. This measure forced over 46 million students across all levels of education to abandon their schools following the closure notice given by the government (The Nigeria Education in Emergency Working Group: EIEWG, 2020).

Unlike the other affected countries, the closure of school in Nigeria did not come with any back-up policy to address the learning disruptions for students (Oyeniran et al., 2020). Thereby, creating new forms of challenges for teaching and learning processes in the country. Based on the observed education practices during the Covid-19 crisis in other countries, the researchers were poised to ask questions like: Are schools prepared for such a sudden change? Do schools have the needed technologies to engage students in remote learning? Do teachers and students have the experiences and resources to prepare, deliver and receive online lessons? Do parents or guardians have the required fund, technology, skills and time to enrol their children in online lessons?

Although, this sudden closure of schools brings about uncomfortable and unprecedented complications and challenges; on the other hand, these measures succeeded in bringing to the spotlight the weakness of the general education system in the country. The Nigeria education system is highly based on traditional classroom education that requires the students to attend school and classes every day. The main educational delivery methodologies are equally traditional face-to-face system, where textbooks, chalkboards or whiteboards are used by the teacher as instructional materials. These do not sufficiently ensure continuous learning during crisis such as the coronavirus pandemic, when students are compulsory kept out of school for safety. Extended closure of schools in the country may come with high social and economic costs and with severe impact on students, especially those from disadvantaged backgrounds (EIEWG, 2020). This is an issue of serious concern, that can only be addressed through online form of education. However, findings of previous researches on technology integration in teaching and learning enterprise in Nigeria's schools revealed that very few public institutions adopted some of the online learning systems and are not using them to the full advantages. In a large scale, the technological literacy of teachers and students are extensively limitations to the effective integration of these educational technologies in schools (Chukwuemeka et al., 2019; Toquero, 2020). Therefore, these challenges have necessitated the need to explore other avenues in order to help students who have been impacted by school closures to stay on course with their educational programmes.

This study is expected to provide information to both the Federal and State ministry of education that will help to step up preparedness toward reducing the impacts of COVID-19 pandemic on the education systems in Nigeria. The paper will significantly provide educators and researchers with literature for the extension of research in the context of Covid-19 pandemic, online learning and education as a whole. The article would be useful for other countries that are yet to implement alternatives to the disrupted in-class learning activities, so that their students will continue to learn from home.

\section{RELATED LITERATURE}

\section{Coronavirus and the Online-learning Platforms in Nigeria}

The UNESCO 2030 education declaration and framework for action require countries "to provide alternative modes of learning for children and young adults who have not enrolled in school (either primary or secondary levels of education) and put in place equivalency by bridging programmes, recognized and accredited by the State's ministry of education, that will ensure flexible learning in both formal and non-formal settings, as well as during emergency situations like the Covid-19 crisis" (UNESCO, 2020). Responding to the current need for alternative learning and education modes in Nigeria, this article evaluates the impact of some online learning platforms capable of facilitating continuous education and recommends them for use during this COVID-19 
pandemic and any future crisis. This review is limited to applications of distance learning, social media, virtual classroom, mobile learning, virtual classroom and flipped classroom.

\section{Distance Learning (DL)}

Due to social distancing measure and the restrictions on mass gathering enforced during the COVID-19 pandemic, schools in many countries across the globe were temporarily closed. As countries around the world are racing to fill the void with online learning solution, uncertainties in the duration of school closure has brought further complications to their effort. This has forced developing countries like Nigeria to look for available and affordable flexible online education modes.

Distance learning is one of the online learning modes that does not necessary require face-to-face meeting. It is essentially a teaching and learning alternative which is given by a mode, where there is physical separation between the teachers and learners or among learners themselves (Jegede, 2016). This mode of online learning provides prevention and control over the spread of the virus (Demuyakor, 2020; Toquero, 2020).

In Nigeria, the quick response to the suspension of school activities due to coronavirus pandemic, witnessed the implementation of distance learning via Television (TV Education). Several state TV stations have immediately commenced airing lessons in various subject areas for the primary and secondary school students (Olapegba et al., 2020). Although, this innovation is seen as a quick fix for the educational challenges arising from sudden closure of schools, but the number of Television connection by households, especially in the remote areas of the country could be low due to limited coverage of TV network (Olapegba et al., 2020). Institutions in Nigeria should consider running tele-courses to provide learning experiences for students in remote areas without internet or without cable TV.

As Nigeria is struggling to go digital, primary and secondary education are often the most vulnerable when it comes to use of technology. This is because online distance learning is usually focused on students of higher institutions of learning, thus leaving out millions of primary and secondary school students (Sintema, 2020). Hence, more affordable and accessible learning experiences should be developed to provide offline distance learning resources for learners, especially those within primary and secondary education located in rural areas. This will help schools to scale up for the lost in-class learning activities (Oyeniran et al., 2020). Both the Federal and State ministry of education should see to the successful implementation of distance learning modes across all levels of education in Nigeria by providing affordable technologies and skills to institutions, teachers and students. This will help the country in the present and future crisis, when learning activities is interrupted.

\section{Social Media (WhatsApp and Facebook)}

The adoption of social media, especially Facebook and WhatsApp into teaching-learning process has significantly increased in recent time. Social media has become the dynamic gateway for delivering educational information across the globe since the detection of COVID-19 pandemic in December, 2019 (Mulenga \& Marban, 2020). This online platform provides educators with a wider range of new and interesting learning experiences and teaching environments, which are not possibly obtainable in the traditional in-class education (Sam, 2016). Thus, the use of Facebook and WhatsApp will offer better chances for online education, especially during the Covid-19 pandemic. It is of paramount importance for schools to use innovative teaching techniques and approaches like the social media during this Covid-19 crisis and beyond (Toquero, 2020).

For many African countries, the advent of COVID-19 could be seen as the birth of new teaching/learning modes (Mulenga \& Marban, 2020). This would include the use of social media platforms like Facebook and WhatsApp. Reddy and Vance (2020) reported that as COVID-19 pandemic sweeps across countries, educators are hosting classroom sessions on social media. Both Facebook and WhatsApp are used to create resources for students and conduct educational discussions (Fischer, 2013). Discussions on these platforms can be synchronous or asynchronous (Arkorful \& Abaidoo, 2014). The use of Facebook and WhatsApp will offer 
access to learning resources anytime and anywhere, and in various forms such as audio, video and print, which potentially will enhance deep learning. It will allow students to construct knowledge by themselves, while they continue to stay away from schools due to Covid-19 pandemic.

In Nigeria, a report released by the Nigerian Communication Commission (NCC, 2019) showed that there were over 24 million active social media users in the country. More than $75 \%$ of social media users are connected to either Facebook or Whatsapp or both. Hence, they are rated the most downloaded applications in the country (NCC, 2019). In fact, the user-friendliness of these two social media sites makes them attractive to people of different ages, backgrounds and location (Chukwuemeka et al., 2019; Romualdo \& Gregorio, 2017). The NCC report revealed further that, there are over 120 million Nigerians connected to the internet and majority of them are youths within the school going age. Therefore, there is need for government to institutionalize the use of social media sites (Facebook and WhatsApp) in schools to encourage remote learning. The use of Facebook and WhatsApp platforms will extend learning to students who were kept out of school since the outbreak of the COVID-19 in the country.

\section{Mobile Learning (M-Learning)}

The introduction of the digital handheld devices and personal computer as well as the consensual acceptance of new pedagogies in the 21st century has speed up a technological revolution that saw more students and teachers increased use of electronic devices in schools. M-Learning is broadly regarded as teaching and learning process that is aided with the use of mobile devices and other related platforms (Pedro, Barbosa, \& Santos, 2018). This form of learning intersects mobile computing and e-learning. It adopts the use of mobile technology such as smartphones, Personal Digital Assistants (PDAs), tablet PCs and laptop PCs to achieve anytime, anywhere, ubiquitous learning, which emphasizes learners' mobility and personalized learning (Chee et al., 2017).

Researches regarding the use of mobile devices as alternative learning mode to in-class learning environment have been carried out even before the advent of COVID-19 pandemic. Subsequent researches conducted during the COVID-19 crisis showed that M-Learning is indeed a learning paradigm that is offering some promising alternative learning avenues, capable of providing exciting learning opportunities to students kept away from schools during the COVID-19 and any future pandemic (Naciri et al., 2020). This is because mlearning is interwoven with everyday activities and can take place anytime and in any locations; not necessary within the four walls of a classroom. It offers students the opportunity to regulate learning according to their pace and styles (Camilleri \& Camilleri, 2017). It allows students to learn, collaborate, and share ideas among themselves (Naciri et al., 2020). Hence, M-learning is an essential educational technology that should be implemented in schools to provide continuous education to the students, especially during this COVID-19 crisis.

While the world is experiencing rapid growth of wireless infrastructure that is providing mobile connectivity to more people each year, it is quite clear that in developing countries like Nigeria, there are very few wireless internet services. The uptake of m-learning is still very low. This is caused by the low internet bandwidth, high internet cost, absence of internet service and wireless infrastructures, most especially among rural communities (NEEWG, 2020). It is based on these, the researchers call on the government of Nigeria to emulate the Kenyan government by expanding her internet coverage across the country; partnering with network providers such as MTN, Globacom and 9mobile to develop Google Loon internet balloons that will carry certain bandwidth of high speed internet connectivity to be floating in areas without internet connectivity. There is also the need for government to support the effort of the non-governmental organisations like "Save-A-Lot" which launched a mobile classroom to enable students from secondary education learn from home. It is a free online platform that requires students to log-in to a web address (www.mobilecrassroom.com.ng) using devices like mobile phones and computers (www.savealot.com.ng). The country can equally adopt "Edupage", a school management digital system adopted and used in over 150,000 schools in 174 countries. According to Basilaia and Kvavadze (2020), Edupage has most of the functions that are suitable for general education process with the basic free functionality such as curriculum, timetable, attendance control, homework, assessment, grading and messaging features. Edupage (2020) has 
made provision for parents and guardians to be part of the process, especially when they are interested in the information about attendance, grades and results of their children. They can communicate with teachers through the system.

Implementation of M-learning in Nigeria at a time when schools are suspended would be a welcomed development. Adoption of M-learning strategy will revolutionized schools in Nigeria. It will offer students the opportunity to learn remotely from home with online tutors, at personalized pace and time of learning (Kayode et al., 2019). Provision of M-learning solution in Nigeria schools can ensure continuous learning, reduce educational vulnerabilities, mitigate the current effect of COVID-19 pandemic and stay better prepared for the future.

\section{Virtual Classroom}

Now that the in-class activities are suspended and learning is moving online. The virtual environment is another option to in-class face-to-face teaching and learning process, which educators can adopt (Yan, 2020). Virtual classroom is a technologically-driven classroom that supports self-directed and self-regulated learning (Xenos, 2018). Virtual classroom offers course materials to the learners. In addition, it is providing live, contextual and interactive environment. Virtual classroom is basically an online classroom setting where the learners together with their teachers, actively engage in synchronous instructional meeting. Like the in-class face-to-face teaching and learning enterprise, virtual classroom will equally require both the instructor and students to log into the classroom at the same time (Huang et al., 2020).

Although it may be new to educators in Nigeria, implementation of virtual classroom will offer the same goal as the face-to-face learning (Falode et al., 2015). It enables students to engage with the material, interact with the instructor and their classmates as well as with the subject matter. Falode et al. (2015) opined that effective implementation of virtual learning platforms like virtual classroom and virtual laboratories in Nigerian schools will have great implication for teaching and learning. Virtual environments have the attributes to stimulate students' interest and motivation in learning, thereby encouraging students' efficiency.

In the context of COVID-19 pandemic, studies regarding the awareness and perception of coronavirus and its impact on education in Nigeria revealed that most schools have not designed e-learning alternatives before the outbreak of the deadly coronavirus that have disrupted education activities in the country (Oyeniran et al., 2020). However, implementation of the online teaching and learning platforms like the virtual classroom will be an initiative that will provide flexible online learning opportunity to millions of students to continue learning from home (Demuyakor, 2020; NEEWG, 2020). It will provide students with the opportunity to access virtual lessons/lectures which will help to reduce anxiety caused by the sudden suspension of all educational gathering and ensure continuity in learning.

Nevertheless, there is need for institutions in Nigeria to adhere to some basic requirements as suggested by Huang et al. (2020). These guidelines will fast rack successful implementation of Virtual Learning Environments that will stand the test of Covid-19 pandemic period. These guidelines include: (i) Building a trustful learning environment by providing continuous engagements, so that learners can feel a sense of belonging to the group and classroom created; (ii) The need to provide timely feedback to learners, so they can find the answers and acquire a sense of achievement in the Virtual classroom; and, (iii) The need to allow learners to gain a sense of emotional identification and release their desire of competition or performance in the virtual classroom.

\section{Flipped Classroom}

Based on the emergency situation of COVID-19, several countries have adopted various flexible teaching and learning modes in their education system (World Bank, 2020). Flipped classroom is one of the main pedagogical approaches adopted during the COVID-19 crisis. In this approach, there is a complete shift of learning from classroom to home while homework is shifted to the classroom. It involves recorded instructions which are delivered online for the students to access, read, watch or listen at their own 
conveniences (Abah et al., 2017). Thus, this offers students flexible opportunities to review lessons by replaying video or audio and study through their preferred learning style, pace, time and location (Huang et al., 2020). This is very helpful in a lockdown situation where both teachers and students are unable to attend classes due to coronavirus pandemic or any other reason.

In spite of its educational significance in ensuring that learning continue at home even when school activities were suspended during crisis, disaster or pandemic such as COVID-19; it has been discovered that flipped classroom approach is yet to be implemented in Nigeria (Abah et al., 2017; Makinde, 2019). But it has come to the focus due to the pressing need for learning approaches that will offer some form of compensatory lessons to students, who due to extension of schools' closure as a result of rising number of COVID-19 cases in Nigeria will continue to stay at home. Thus, flipped classroom alongside other flexible pedagogical approaches can be implemented in Nigeria.

Furthermore, in a country like Nigeria where not all students have access to the internet and where the broad bandwidth for internet access is low - below $4 \mathrm{G}$, a miniature of a flipped classroom model will make an impact in time of crisis that would demand closure of schools. In this form of a flipped classroom, educators will be required to create lessons, doing the necessary presentations and demonstrations by standing in front of a camera and recording the whole lesson(s) or topic(s) to be taught within a term/semester or even a session. The recorded lesson(s) will be presented on Flash Drives, CD, VCD, MP3, MP4, DVD and even on TV. These materials may be given to students at registration points, which they will take away to their homes, where they will play it repeatedly at their own conveniences while discussions will be done in the class any time schools are opened.

\section{CONCLUSION}

The emergence of this paper is in congruence with the disruption of in-class face-to-face teaching and learning structures as a result of the outbreak of Covid-19 in Nigeria. To effectively and efficiently respond to the threat of the Covid-19 pandemic on education in the country, schools need to move to online learning using any of the reviewed flexible teaching and learning modes. The justification for the adoption of these online education delivery modes as veritable tools to catalyse continuity in education in the face of imminent closure of schools does not require any long argument from government and all stakeholders involved. These alternative pedagogical approaches presented will offer new ways of learning, taking into account the possibilities of both synchronously and asynchronously educational communication, as against the very limited current learning strategy that suspended teaching and learning during the coronavirus pandemic. Hence, as the total transition from physical classroom to other flexible learning modes is encouraged during this COVID-19 crisis, the basic requirement is the commitment of all stakeholders involved, towards the full implementation of these learning modes which were currently weakened by the haphazard policy formulation and execution, coupled with the lack of funding of the system and regulatory activities to guide educational development in Nigeria during and after this crisis.

\section{RECOMMENDATIONS}

- It is recommended that the Federal and State government should expand coverage of distance learning beyond just the tertiary institutions to cover the secondary and elementary schools in the country as catalyst to ensure continuity in education during the days of crisis when in-class activities may be suspended.

- Both Federal and State government ministry of education should encourage schools to create social media pages and credible education portals where students can log-in to access learning contents and where they can constantly make contact with their teachers and peers through group chats and undertake and submit assessment anytime and anywhere.

- Since it may be difficult to operate full online learning in Nigeria especially during this current situation, it is recommended that both the Federal and State governments should implement tele-courses through 
Radio, TV and telephone network providers to keep students educationally engaged during the Covid-19 pandemic and any future disaster.

- It is recommended that due to the situation of uncertainty caused by the coronavirus and the need for continuity of teaching and learning in Nigeria, mobile learning should be implemented as an essential educational technology component, which will allow students to learn, collaborate, and share ideas while they continue to stay at home.

- It is recommended that the Nigerian government should partner with the telecommunication service providers such as MTN, Globacom and 9mobile among others to develop Google's Loon Balloons that can carry $4 \mathrm{G}$ base stations which will be set to float over the country's airspace to provide wireless internet connectivity network, particularly to rural and remote communities, so that students residing in these remote communities can access online learning and other educational resources.

- Students who were the most affected group by this sudden shut down of schools are encouraged to start up discussion groups for collaborative learning using any of the social media platforms. They can also engage their teachers in the discussion and undertake quizzes in other to access their level of progression in learning.

- Further studies need to be done to determine the post COVID-19 intervention strategies that will aid in transforming and advancing teaching and learning processes in the country.

\section{REFERENCES}

Abah, J., Anyagh, P., \& Age, T. (2017). A flipped applied mathematics classroom: Nigerian university students' experience and perceptions. ABACUS, The Mathematical Association of Nigeria. Mathematics Education Series, 42(1), 78-87. hal-01596571. Retrieved on 6 April 2020 from https://hal.archivesouvertes.fr/hal-01596571

Akwa, T. E., Ning, T. R., \& Maingi, J. M. (2020). Assessing the Perceptions and Awareness of COVID-19 (Coronavirus) in Cameroon. European Journal of Medical and Educational Technologies, 13(2), em2007. https://doi.org/10.30935/ejmets/8236

Arkorful, V., \& Abaidoo, N. (2014). The role of e-learning, the advantages and disadvantages of its adoption in higher education. International Journal of Education and Research, 2(12), 398-410.

Bao, W. (2020). COVID-19 and online teaching in higher education: A case study of Peking University. Human Behavior and Emerging Technologies, 2, 113-115. Retrieved on 2 April 2020 from https://doi.org/10.1002/hbe2.191

Basilaia, G., \& Kvavadze, D. (2020). Transition to Online Education in Schools during a SARS-CoV-2 Coronavirus (COVID-19) Pandemic in Georgia. Pedagogical Research, 5(4), em0060. https://doi.org/10.29333/pr/7937

Brooks, S. K., Webster, R. K., Smith, L. E., Woodland, L., Wessely, S., Greenberg, N., \& Rubin, G. J. (2020). The psychological impact of quarantine and how to reduce it: rapid review of the evidence. The Lancet, 395(10227), 912-920. https://doi.org/10.1016/S0140-6736(20)30460-8

Camilleri, M. A., \& Camilleri, A. C. (2017). The technology acceptance of mobile Applications in education. Proceeding of the 13th International Conference on Mobile Learning: international association for development of information society (iadis), Budapest, Hungary.

Chee, K. N., Yahaya, N., Ibrahim, N. H., \& Noor Hassan, M. (2017). Review of mobile learning trends 20102015: A meta-analysis. Educational Technology \& Society, 20(2), 113-126. 
Chukwuemeka, E. J., Nsofor, C. C., Falode, O. C., \& Aniah, A. (2019). Assessing Pre-Service Teachers' Technological Pedagogical Content Knowledge Self-Efficacy towards Technology Integration in Colleges of Education in South-West Nigeria. Journal of Science, Technology, Mathematics and Education (JOSMED), 15(3), 143-151.

Demuyakor, J. (2020). Coronavirus (COVID-19) and Online Learning in Higher Institutions of Education: A Survey of the Perceptions of Ghanaian International Students in China. Online Journal of Communication and Media Technologies, 10(3), e202018. https://doi.org/10.29333/ojcmt/8286

Edupage (2020). EduPage features. Retrieved on 8 April 2020 from https://www.edupage.org/

Falode, O.C., Gambari, A. I., Shittu, T., Gimba, R. W., Falode, M. E., \& Awoyemi, D. I. (2015). Effectiness of vitual classroom in teaching and learning of senior secondary school mathematics concepts in Minna, Nigeria. Indo-African Journal of Educational Research, 3(4), 1-4. Retrieved on 2 April 2020 from http://iajer.rstpublishers.com/

Federal Ministry of Education. (2002). Blueprint and Implementation Plan for National Open and Distance Learning Programmes.

Fischer, Y. (2013). The Facebook is dead-long live WhatsApp. De Marker. Retrieved on 23 March 2020 from http://www.themarker.com/technation/1.2126492

Fong, S. J., Li, G., Dey, N., Crespo, R. G., \& Viedma, E. H. (2020). Composite monte carlo decision making under high uncertainty of novel coronavirus epidemic using hybridized deep learning and fuzzy rule induction. Applied Soft Computing Journal, 93, 106282. https://doi.org/10.1016/j.asoc.2020.106282

Huang, R. H., Liu, D. J., Tlili, A., Yang, J. F., Wang, H. H., et al. (2020). Handbook on Facilitating Flexible Learning During Educational Disruption: The Chinese Experience in Maintaining Undisrupted Learning in COVID19 Outbreak. Beijing: Smart Learning Institute of Beijing Normal University. Retrieved on 2 April 2020 from http://creativecommons.org/licenses/by-sa/3.0/igo/

Jegede, O. (2016) Open and Distance Learning Practices in Nigerian Higher Institution of Learning. A Keynote Address at the $3^{\text {rd }}$ University of Ibadan Annual Distance Learning Centre Distinguished Lecture and Stakeholders' Forum Held at the International Conference Centre, University of Ibadan, Thursday, $14^{\text {th }}$ and Friday, $15^{\text {th }}$ July, 2016.

Johns Hopkins University. Coronavirus Resource Center (2020). COVID-19 Dashboard by the Center for Systems Science and Engineering (CSSE) at Johns Hopkins University (JHU). Retrieved on 1 May 2020 from https://coronavirus.jhu.edu/map.html

Kayode, D. J., Alabi, A. T., Sofoluwe, A. O., \& Oduwaiye, R. O. (2019). Problems and challenges of mobile learning in Nigerian university system. In: Y. Zhang \& D. Cristol (eds), Handbook of Mobile Teaching and Learning. Springer, Berlin, Heidelberg. https://doi.org/10.1007/978-981-13-2766-7_135

Makinde, S. (2019). Effects of a developed flipped classroom package on senior secondary school students' performance in mathematics in Lagos, Nigeria. Retrieved on 29 March 2020 from https://www.researchgate.net/publication/334046113

Mulenga, E. A., \& Marbán, J. A. (2020). Is covid-19 the gateway for digital learning in mathematics education? Contemporary Educational Technology, 12(2), ep269. https://doi.org/10.30935/cedtech/7949

Naciri, A., Baba, M. A., Achbani, A., \& Kharbach, A. (2020). Mobile Learning in Higher Education: Unavoidable Alternative during COVID-19. Aquademia, 4(1), ep20016. https://doi.org/10.29333/aquademia/8227

Nigeria Communication Commission: 2019 online statistics. Retrieved from www.ncc.org.ng

Nigeria Education in Emergencies Working Group (2020). Nigeria Education Sector COVID-19 Response Strategy in North East. Retrieved on 3 April 2020 from www.eiewg.gov.ng 
Olapegba, P. O., Ayandele, O., Kolawole, S. O., Oguntayo, R., Gandi, J. C., Dangiwa, A. L., ... Iorfa, S. K. (2020). A Preliminary Assessment of Novel Coronavirus (COVID-19) Knowledge and Perceptions in Nigeria. SSRN Electronic Journal. https://doi.org/10.2139/ssrn.3584408

Otu, A., Ameh, S., Osifo-Dawodu, E., Alade, E., Ekuri, S., \& Idris, J. (2017). An account of the Ebola virus diesaes outbreak in Nigeria: implications and lessons learnt. BMC Publich Health, 17(1), 736. https://doi.org/10.1186/s12889-4535-x

Oyeniran, O. A., Oyeniyi, J., \& Oyeniran, A. (2020). E-Learning: Advancement in Nigerian pedagogy amid Covid-19 pandemic. International Journal of Multidisciplinary Sciences and Advanced Technology, 1, 85-94. Retrieved on 2 April 2020 from http://www.ijmsat.com

Pedro, L. F. M. G., Barbosa, C. M. M. D., \& Santos, C. M. D. (2018). A critical review of mobile learning integration in formal education contexts. International Journal of Technology Higher Education, 15, 10. https://doi.org/10.1186/s41239-018-0091-4

Reddy, A., \& Vance, A. (2020). Social (Media) distancing: Online Learning during a pandemic. Retrieved on 26 March 2020 from https://ferpasherpa.org/social-media-distancing-covid19/

Romualdo, A. M., \& Gregorio, P. E, Jr. (2017). Facebook Integration into University Classes: Opportunities and Challenges. The $31^{\text {st }}$ Pacific Asia Conference on Language, Information and Computation (PACLIC 31), 265-273, Cebu City, Philippines.

Sam, D. P. (2016). Learning beyond the Classroom through WhatsApp: An Informal Channel to Motivate Learners to stay Connected. Asian Journal of Research in Social Sciences and Humanities, 6(9), 18261833. https://doi.org/10.5958/2249-7315.2016.00910.2

Save-A-Lot (2020). Covid-19 Impact: Mobile Classroom App declare portal free for Nigerian students as federal government shut-down schools nationwide. Retrieved on 27 March 2020 from www.savealot.com.ng

Sintema, E. J. (2020a). Effect of COVID-19 on the Performance of Grade 12 Students: Implications for STEM Education. Eurasia Journal of Mathematics, Science and Technology Education, 16(7), em1851. https://doi.org/10.29333/ejmste/7893

Sintema, E. J. (2020b). E-Learning and Smart Revision Portal for Zambian Primary and Secondary School Learners: A Digitalized Virtual Classroom in the COVID-19 Era and Beyond. Aquademia, 4(2), ep20017. https://doi.org/10.29333/aquademia/8253

Toquero, C. M. (2020). Challenges and Opportunities for Higher Education amid the COVID-19 Pandemic: The Philippine Context. Pedagogical Research, 5(4), 1-5. https://doi.org/10.29333/pr/7947

UNESCO (2020). The new Education 2030 Agenda. Retrieved from http://unesdoc.unesco.org/neweducation-2030-agenda

United States of America Department of Health and Human Services / Centers for Disease Control and Prevention (2020). 2019-nCoV Report. Retrieved on 25 March 2020 from https://www.cdc.gov/coronavirus/2019-nCoV/lab/guidelines-clinical-specimens.html

WHO (2020, 12 January). Emergencies preparedness, response. Pneumonia of unknown origin - China. Disease outbreak news. Retrieved on 25 February 2020 from https://www.who.int/csr/don/12january-2020-novel-coronavirus- china/en/

WHO. (2020). Novel coronavirus (2019-nCoV). Situation Report 1. Geneva, Switzerland: World Health Organization. Retrieved on 25 February 2020 from https://www.who.int/docs/defaultsource/coronaviruse/situation-reports/20200121-sitrep-1-2019-ncov.pdf?sfvrsn 
World Bank. (2020, April). How countries are using edtech (including online learning, radio, television, texting) to support access to remote learning during the COVID-19 pandemic. Retrieved on 7 April 2020 from www.worldbank.org/en/topic/edutech/brief/how-countries-are-using-edtech-to-support-remotelearning-during-the-covid-19-pandemic

World Bank. (2020, April). The Economy in the time of Covid-19. LAC Semiannual Report. Washington DC: World Bank. Retrieved on 13 April 2020 from https://openknowledge.worldbank.org/handle/10986/33555

Xenos M. (2018). The future of virtual classroom: Using existing features to move beyond traditional classroom limitations. In M. Auer \& T. Tsiatsos (eds), Interactive Mobile Communication Technologies and Learning. Advances in Intelligent Systems and Computing, 725, 944-951. https://doi.org/10.1007/978-3-319-75175-7_92

Yan, Z. (2020). Unprecedented pandemic, unprecedented shift, and unprecedented opportunity. Human Behavior and Emerging Technologies, 2, 110-112. https://doi.org/10.1002/hbe2.192

Correspondence: Emeka Joshua Chukwuemeka, Department of Educational Technology Federal University of Technology, Minna, Niger State, Nigeria. E-mail: emekac.joshua@gmail.com 